\title{
Enzymatic polyphenoloxidase inactivation with temperature and ozone in sugarcane variety RB 92579 to produce lower color sugar
}

\section{Inativação de polifenoloxidase enzimática com temperatura e ozônio na variedade de cana-de-açúcar RB 92579 para produzir açúcar de cor mais clara}

Ana Carla Borba de Azevedo ${ }^{1}$, Flávio Luiz Honorato da Silva ${ }^{1}$, Lorena Lucena de Medeiros ${ }^{1}$, Angela Lima Menêses de Queiroz ${ }^{1 *}$ (1) , Sharline Florentino de Melo Santos ${ }^{1}$, Josivanda Palmeira Gomes ${ }^{2}$, Juliana Andreza Figuerôa ${ }^{2}$

${ }^{1}$ Universidade Federal da Paraíba (UFPB), Centro de Tecnologia, Departamento de Engenharia de Alimentos, João Pessoa/PB - Brasil

2Universidade Federal de Campina Grande (UFCG), Centro de Ciência e Tecnologia, Campina Grande/PB - Brasil

Corresponding Author: Angela Lima Menêses de Queiroz, Universidade Federal da Paraíba (UFPB), Centro de Tecnologia, Departamento de Engenharia de Alimentos, Cidade Universitária, CEP: 58051-900, João Pessoa/PB Brasil, e-mail: angelalimas@gmail.com

Cite as: Azevedo, A. C. B., Silva, F. L. H., Medeiros, L. L., Queiroz, A. L. M., Santos, S. F. M., Gomes, J. P., \& Figuerôa, J. A. Enzymatic polyphenoloxidase inactivation with temperature and ozone in sugarcane variety RB 92579 to produce lower color sugar. Brazilian Journal of Food Technology, 22, e2018043. https://doi.org/10.1590/1981-6723.04318

\begin{abstract}
Some sugarcane varieties have high activity of polyphenoloxidase enzyme, impairing the production of lower color sugar. Polyphenoloxidase (PPO) is an enzyme from the oxidoreductases group and it is present in a greater or lesser amount depending on the sugarcane variety, climatic conditions, age, culture treatment, harvest and processing conditions. The presence of this enzyme has great impact in the food industry, as it is the main enzyme involved in the undesirable darkening of fruits and vegetables during processing and storage. It is of great importance for the food industry to study inactivation methods for this enzyme. The aim of this work was to evaluate the effect of ozone gas associated (replacement of the conventional sulphitation process), whose concentrations were 150,300 and $450 \mathrm{mg} / \mathrm{L}$, at the inactivation temperature of polyphenoloxidase enzyme of sugarcane variety RB 92579 for the production of lower color sugar. Treatment with ozone concentration of $150 \mathrm{mg} \cdot \mathrm{L}^{-1}$ at $105^{\circ} \mathrm{C}$ showed direct correlation between juice color reduction and enzyme inactivation, resulting in the production of lower color sugar.
\end{abstract}

Keywords: Clarification; Enzyme; Ozone gas; Sugar color index; Agro-industrial process; Sucrose.

\section{Resumo}

Algumas variedades de cana têm alta atividade da enzima polifenoloxidase, prejudicando o processo de produção de açúcar de cor menos escura. Polifenoloxidase (PPO) é uma enzima pertencente ao grupo de oxidorredutases e 
está presente numa quantidade maior ou menor, dependendo da variedade de cana-de-açúcar, das condições climáticas, da idade, do tratamento da cultura, da colheita e das condições de processamento. A presença dessa enzima tem grande impacto na indústria de alimentos por ser a principal enzima envolvida no indesejável escurecimento de frutas e vegetais durante o processamento e armazenamento. É de grande importância para a indústria de alimentos estudar métodos para a inativação desta enzima. O objetivo deste trabalho foi avaliar o efeito do gás ozônio associado em substituição da sulfatação convencional do processo, nas concentrações foram de 150, 300 e 450 mg/L, na temperatura de inativação da enzima polifenoloxidase (da variedade de cana-de-açúcar RB 92579) para a produção de açúcar de cor mais clara. O tratamento com ozônio aplicado com concentração de 150 mg. $\mathrm{L}^{-1}$ mostrou uma correlação direta entre a redução na cor do caldo e a inativação da enzima, resultando na produção de açúcar de cor mais clara.

Palavras-chave: Clarificação; Enzima; Gás ozônio; Índice de cor de açúcar; Processo agroindustrial; Sacarose.

\section{Introduction}

Currently, sugarcane has highly diversified varieties and it is a crop of great economic importance for its high efficiency in the sugar production process (Batista et al., 2013). In the sugarcane production system, the cultivation of varieties with suitable agro-industrial characteristics is the most consistent way to obtain productivity and quality improvements (Almeida et al., 2009; Fagundes et al., 2014).

Sugarcane variety RB92579 is currently the most widely grown in northeastern Brazil. It has stood out with a productivity up to $30 \%$ higher (Centro de Previsão de Tempo e Estudos Climáticos, 2008), but in most places, RB92579 presents dark juice due to the high content of phenols, greater than $1000 \mathrm{mg} \mathrm{L}^{-1}$ (Quintela et al., 2015; Azevedo et al., 2014).

During sugarcane processing, plant tissues are broken, as a result of metabolic disorders, often undesirable, from the release of enzymes related to the oxidation of phenolic compounds, which are subsequently polymerized to dark-colored pigments (Icier et al., 2008; Jakób et al., 2010).

Inhibition and/or control of metabolic changes caused by enzymes are of maximum important to maintain the quality level in the final product. The control of enzymatic browning can be done by physical and/or chemical methods. The sugarcane juice color is fundamental for the production of lower color sugar (Silva et al., 2015).

Currently, ion exchange resins and activated carbon are used in the clarification of refined sugar. However, these methodologies are expensive, require constant recovery/regeneration, and cause loss of capacity due to processing time. Therefore, alternative technologies have been studied for this purpose, in order to increase the sector's economy (Mandro et al., 2017). In order to substitute sulfur in the sugar production, new potentials have been studied, among which are the Advanced Oxidative Processes, such as ozone and hydrogen peroxide (Santori et al., 2015). Ozonation in clarification oxidizes organic compounds in the juice treatment, showing low color juice, with several advantages over the use of sulfur (Silva et al., 2011). Silva et al. (2015) have reported deficiency of sulfite oxidase enzyme in humans and related allergies caused by sulphite.

By the ozonation process, pigments present in the juice are degraded, which reflects in reduced color of sugar produced. Studies on its use in the treatment of sugarcane juice are still scarce; therefore, the aim of this work was to evaluate the effect of ozone gas associated (replacement of the conventional sulphitation process) at the inactivation temperature of polyphenoloxidase enzyme of sugarcane variety RB 92579 for the production of lower color sugar. 


\section{Material and methods}

This work was developed in Industrial laboratories of Usina São João Company, Santa Rita-PB ( $7^{\circ} 7^{\prime} 50,0^{\prime \prime}$ lat, $35^{\circ} 00^{\prime} 55,7^{\prime \prime}$ long) and collaboration of Gasil Company (Jaboatão-PE), which provided the ozone generator. About $80 \mathrm{~kg}$ of sugarcane variety RB 92579 in the mature stage (unburned and burnt) were used. Samples were collected at São Gonçalo Farm, a property of Usina São João Company.

In the clarification process, the broth $(2 \mathrm{~L})$ was treated with ozone under constant stirring for $30 \mathrm{~min}$ (Figure 1); amounts of 5, 10 and $15 \mathrm{mg} \mathrm{O}_{3} \mathrm{~min}^{-1}$ were injected in the reactor. The temperature in the reactor was around $30{ }^{\circ} \mathrm{C}$. The $\mathrm{pH}$ was analyzed before and after the ozone treatment, but not controlled during ozonation.

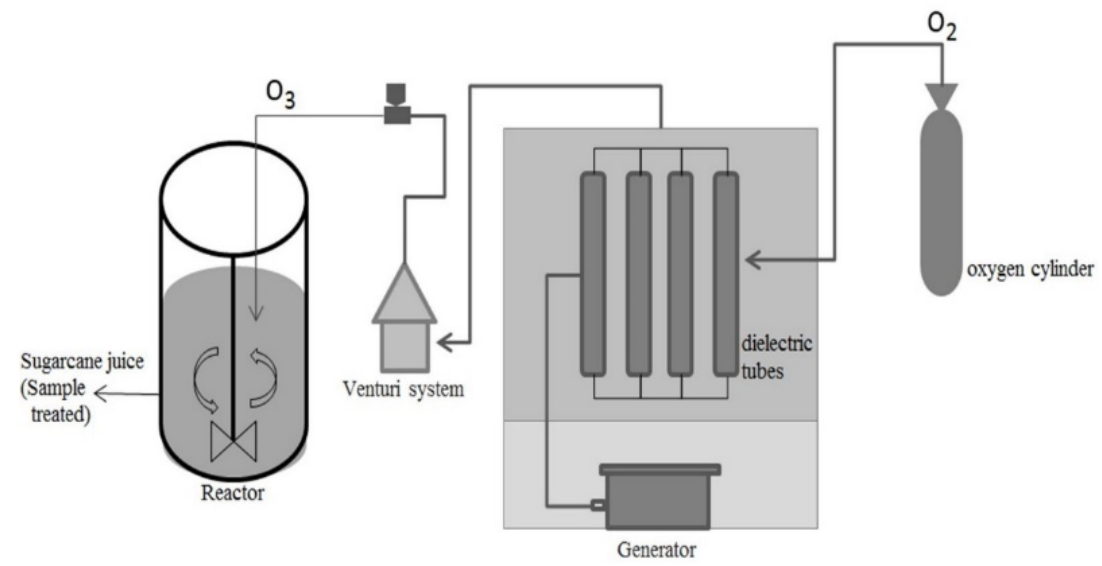

Figure 1. Pilot system for ozone generation.

The system basically consists of dielectric tubes where oxygen - which receives a steady electric discharge (corona), generated through a high voltage transformer (21,000 volts) converting oxygen molecule $\left(\mathrm{O}_{2}\right)$ in ozone molecule $\left(\mathrm{O}_{3}\right)$ - is suctioned by the "Venturi" system and is bubbled, by a silicone hose, into the broth under treatment.

The analyzes were performed in triplicate of juices derived from the processing of burnt sugarcane variety RB92579 and control sample. Analyzes for determining the polyphenoloxidase enzymatic activity, pH, juice color, reducing sugar, TSS ( ${ }^{\circ}$ Brix), pol (apparent sucrose) were performed.

For all procedures, sugarcane samples were homogenized, crushed in forage and pressed into Codistil probe. The juice was homogenized and separated into $2 \mathrm{~L}$ aliquot for each sample to be treated with ozone gas at concentrations of 150,300 and $450 \mathrm{mg} / \mathrm{L}$ and thermal treatment in heater plate at $105{ }^{\circ} \mathrm{C} \pm 5{ }^{\circ} \mathrm{C}$ (polyphenoloxidase enzyme inactivation).

The $\mathrm{pH}$ analysis was carried out in a digital $\mathrm{pH}$ meter (QUIMIS) with combined glass electrode and temperature probe. The equipment was calibrated with $\mathrm{pH} 4.0$ and 7.0 solutions. Reading was performed at $20^{\circ} \mathrm{C}$.

Total soluble solids ( ${ }^{\circ}$ Brix) were measured in a refractometer model RFM 712, Bellingham Stanley. The equipment was calibrated with distilled water and the reading was adjusted when necessary to zero value in the ${ }^{\circ}$ Brix scale.

For the juice analysis, after calibrating the apparatus, two sample drops were placed on the cleaned and dried prism, and after a few seconds, when the juice temperature reached the prism temperature, the refractometric ${ }^{\circ}$ Brix reading was performed.

The reducing sugar content (AR) of juices was determined by the Eynon and Lane method described by Zago et al. (1992). 
The ICUMSA color measurement of the sugarcane juice (International Commission for Uniform Methods of Sugar Analysis, 1935) was previously determined by diluting the juice to a concentration of $1{ }^{\circ} \mathrm{Brix}$ and vacuum filtering through a membrane with $0.45 \mathrm{~mm}$ porosity and $50 \mathrm{~mm}$ diameter.

The solution $\mathrm{pH}$ was adjusted to $7.00 \pm 0.05$ with $0.05 \mathrm{~mol} \cdot \mathrm{L}^{-1}$ of sodium hydroxide solution, and the absorbance reading was performed in a spectrophotometer in $1 \mathrm{~cm}$ glass cuvette, and wavelength equal to $420 \mathrm{~nm}$. The color index was determined by the Equation 1 .

$$
\text { ICUMSA Color }=\frac{\left(\operatorname{Abs}^{420 \mathrm{~nm}} \times 1000\right)}{\left[\rho \times\left(\text { Brix }_{c} / 100\right)\right]}
$$

Where:

Brix $_{\mathrm{c}}$ - concentration of TSS in the diluted sample; and

$\rho$ - sample density.

Enzyme inactivation analysis was performed for each treatment using catechol as phenolic substrate, according to the method described by Campos et al. (1996). The polyphenoloxidase enzymatic activity is defined as one unit of enzyme capable of increasing absorbance $(425 \mathrm{~nm})$ by 0.001 unit per minute.

Results were submitted to analysis of variance (ANOVA) at 5\% probability, by the Tukey test, through the software Assistat version 7.6 (Silva, 2016).

\section{Results and discussion}

Table 1 shows the physicochemical characterization of juices from burnt (fresh) and unburned sugarcane in the respective treatments.

Table 1. Physicochemical characterization of juices from burnt (fresh) and unburned sugarcane.

\begin{tabular}{|c|c|c|c|c|c|c|c|c|}
\hline Treatments & $\mathbf{p H}^{*}$ & $\mathbf{p H} \mathbf{H}^{* *}$ & $\begin{array}{l}\mathrm{AR}^{*} \\
(\%)\end{array}$ & $\begin{array}{l}A R^{* * *} \\
(\%)\end{array}$ & $\begin{array}{c}\text { TSS* } \\
\left({ }^{\circ} \text { Brix }\right) \\
\end{array}$ & $\begin{array}{l}\text { TSS*** } \\
\text { ('Brix) }\end{array}$ & $\begin{array}{l}\text { Pol* } \\
(\%)\end{array}$ & $\begin{array}{c}\text { Pol** } \\
(\%)\end{array}$ \\
\hline $\mathrm{T} 1$ & $4.91 \mathrm{Aa}$ & $4.85 \mathrm{Ba}$ & $0.95 \mathrm{Bc}$ & $1.25 \mathrm{~B} \mathrm{a}$ & $20.51 \mathrm{Aa}$ & $17.90 \mathrm{Ba}$ & $17.85 \mathrm{Ba}$ & $12.68 \mathrm{Bb}$ \\
\hline $\mathrm{T} 2$ & $4.85 \mathrm{Ab}$ & $4.65 \mathrm{Bb}$ & $0.98 \mathrm{Bc}$ & $1.15 \mathrm{Ac}$ & $20.29 \mathrm{Ab}$ & $17.85 \mathrm{Ba}$ & $16.95 \mathrm{Aa}$ & $12.65 \mathrm{Bb}$ \\
\hline $\mathrm{T} 3$ & $4.76 \mathrm{Ac}$ & $4.60 \mathrm{Bc}$ & $1.09 \mathrm{Bb}$ & $1.19 \mathrm{Ab}$ & $20.37 \mathrm{Ab}$ & $17.75 \mathrm{Bb}$ & $16.96 \mathrm{Aa}$ & $12.67 \mathrm{Bb}$ \\
\hline $\mathrm{T} 4$ & $4.61 \mathrm{Ad}$ & $4.58 \mathrm{Bd}$ & $1.25 \mathrm{Ba}$ & $1.28 \mathrm{Aa}$ & $20.48 \mathrm{Aa}$ & $17.85 \mathrm{Ba}$ & $16.96 \mathrm{Aa}$ & $12.76 \mathrm{Ba}$ \\
\hline
\end{tabular}

*Unburned sugarcane; **Burnt sugarcane; Tukey test with $p<0.05$; different lowercase letters in columns indicate statistical difference between treatments; different capital letters in lines indicate statistical difference between unburned and burnt sugarcane for each parameter; $\mathrm{T} 1$ - Characterization of fresh sugarcane juice without treatment, T2 - Characterization of fresh sugarcane juice with treatment of $150 \mathrm{mg} \cdot \mathrm{L}^{-1}$ of ozone at temperature of $105^{\circ} \mathrm{C}, \mathrm{T} 3$ - Characterization of fresh sugarcane juice with treatment of $300 \mathrm{mg} \cdot \mathrm{L}^{-1}$ of ozone at temperature of $105^{\circ} \mathrm{C}, \mathrm{T} 4=$ Characterization of fresh sugarcane juice with treatment of $450 \mathrm{mg} \mathrm{L}^{-1}$ of ozone at temperature of $105^{\circ} \mathrm{C}$. AR - reducing sugar; TSS - Soluble solids content; Pol - apparent sucrose.

Table 1 shows that $\mathrm{pH}$ decreased as ozone concentration for juice from unburned and burnt sugarcane was increased. Changes in $\mathrm{pH}$ may be associated with changes in the ozone decomposition rate. At high $\mathrm{pH}$, ozone degrades rapidly and together with aqueous solution can form various radioactive oxidants (Silva et al., 2011).

Silva et al. (2015) found $\mathrm{pH}$ of 4.07 and 4.95 for non-heated sugarcane juice and sugarcane juice heated, respectively; these values are similar to those found in this study. We observed that there was a significant difference between the data.

According to Siles et al. (2011), $\mathrm{pH}$ reduction along with $\mathrm{O}_{3}$ concentration increase is probably due to the production of acidic compounds such as acetic acid and oxalic acid, and the formation of hydroxyl radicals, where ozone decomposes in the aqueous phase. 
Regarding the influence of the sugarcane type, unburned or burnt, the $\mathrm{pH}$ of juices differs, and $\mathrm{pH}$ is reduced in the juice from burnt sugarcane.

Regarding the treatments influence in the evaluation of reducing sugars (RA), it was observed that, for cane juice burnt or unburned, there is a significant increase as the ozone concentration in the environment increases, but no significant difference among the evaluated treatments.

Juice from burnt sugarcane presents, in general, higher AR value, which is explained by the partial hydrolysis of sucrose into reducing sugars due to high temperatures that sugarcane was exposed to in the firing process.

The variation in total soluble solids (TSS) in the different treatments, in general, was not perceived, but a comparison of juices from unburned and burnt sugarcane is quite relevant, with lower ${ }^{\circ}$ Brix values in juices from burnt sugarcane $(p<0.05)$.

Silva et al. (2015) verified similar TSS values ranging from 20.9 to 23.0, for unheated and heated sugar cane.

Regarding pol (apparent sucrose), the treatments influence follow the same behavior observed for TSS, i.e., there is no statistical variation of this variable as a function of the increased ozone concentration.

Barbosa et al. (2013) studied the fertirrigated sugarcane with vinasse via surface drip irrigation in three cane-stalk cycles and verified a variation in TSS and pol values with 225, 245 and 305 days after harvest. TSS results ranged from 18 to $19^{\circ}$ Brix with 225 days to 20 to $21^{\circ}$ Brix in 305 days. Regarding the sucrose content (pol) present in samples with 225 days, the content was 15 to $16 \%$ to 17 to $18 \%$ with 305 days, values close to those found in this research.

However, comparing the juice from burnt sugar cane and from unburned sugarcane (fresh), there is a significant influence $(p<0.05)$, with a marked decrease in sucrose values of juice from burnt sugarcane. This is due to the inversion of sucrose into reducing sugars by high temperatures in the sugarcane burning process (Santos et al., 2011).

Figures 2A, 2B, 2C and 2D show the absorbance profiles in analyzes of polyphenoloxidase enzymatic activity using untreated juice, treated juice with $150 \mathrm{mg} \mathrm{L}^{-1}$, treated juice with $300 \mathrm{mg} \mathrm{L}^{-1}$ and treated juice with $450 \mathrm{mg} \mathrm{L}^{-1}$ of ozone and temperature of $105^{\circ} \mathrm{C} \pm 5^{\circ} \mathrm{C}$.
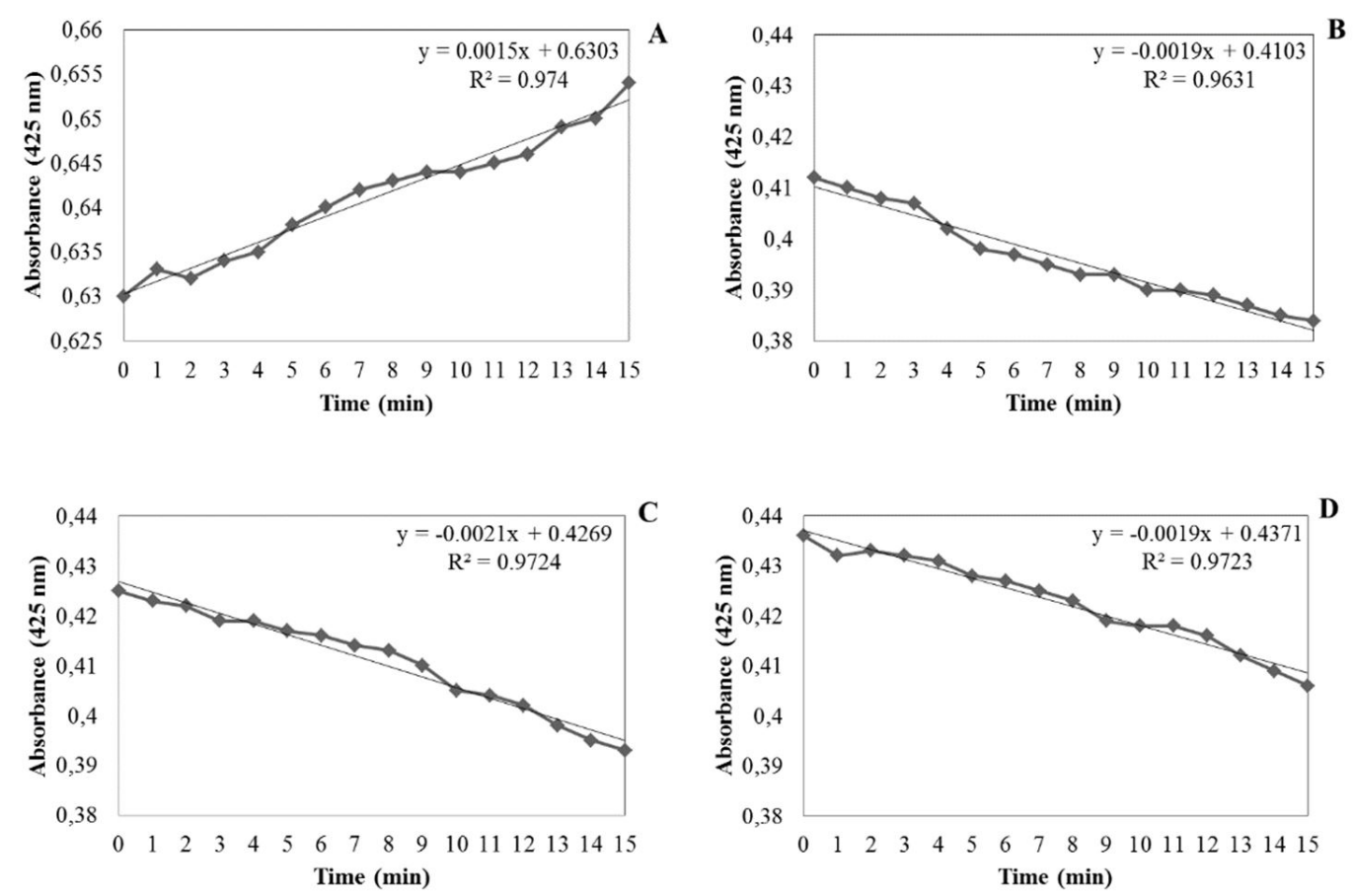

Figure 2. Analyzes of polyphenoloxidase enzymatic activity using untreated juice (A), treated juice with $150 \mathrm{mg} \mathrm{L}-1$, (B), treated juice with $300 \mathrm{mg} \mathrm{L}-1$ (C) and treated juice with $450 \mathrm{mg} \mathrm{L}-1$ (D) of ozone and temperature of $105^{\circ} \mathrm{C} \pm 5^{\circ} \mathrm{C}$. 
Treatments showed that juice samples from burnt sugarcane when treated with ozone at different concentrations (150 mg L-1, $300 \mathrm{mg} \mathrm{L}^{-1}$ and $\left.450 \mathrm{mg} \mathrm{L}^{-1}\right)$ and temperatures of $105{ }^{\circ} \mathrm{C} \pm 5{ }^{\circ} \mathrm{C}$ showed decreasing absorbance profiles throughout the analysis time, as expected.

In Figure 2, juice from untreated burnt sugarcane showed absorbance between 0.660 and 0.625 , reflecting an increase in the polyphenoloxidase enzymatic activity and in the sugarcane juice color. Sugarcane juice samples treated with ozone showed a reduction in absorbance readings when compared to untreated sugarcane juice.

This decrease in absorbance directly reflected in the color reduction, showing that treatments partially inactivate the action of polyphenoloxidase enzyme in treated juices.

Figures $2 \mathrm{~B}, 2 \mathrm{C}$ and $2 \mathrm{D}$ show the absorbance decrease and Table 2 shows the juices color decrease according to treatments.

Table 2. ICUMSA color characterization of juice from burned sugarcane in different treatments.

\begin{tabular}{cc}
\hline Treatments & ICUMSA Color \\
\hline T1 & $27.266 \mathrm{a}$ \\
T2 & $17.203 \mathrm{~b}$ \\
T3 & $17.752 \mathrm{~b}$ \\
$\mathrm{~T} 4$ & $17.921 \mathrm{~b}$ \\
\hline
\end{tabular}

Tukey test with $p<0.05$; different letters indicate statistic difference between treatments; T1 - Characterization of fresh sugarcane juice without treatment, T2 - Characterization of fresh sugarcane juice with treatment of $150 \mathrm{mg} \cdot \mathrm{L}^{-1}$ of ozone at temperature of $105^{\circ} \mathrm{C}, \mathrm{T} 3$ - Characterization of fresh sugarcane juice with treatment of $300 \mathrm{mg} \cdot \mathrm{L}^{-1}$ of ozone at temperature of $105^{\circ} \mathrm{C}$, T4 $=$ Characterization of fresh sugarcane juice with treatment of $450 \mathrm{mg} \cdot \mathrm{L}^{-1}$ of ozone at temperature of $105^{\circ} \mathrm{C}$.

The combination of ozone concentration (influence on color reduction) and temperature (enzyme inactivation) were effective in reducing the juice color (Table 2). A reduction in absorbance values was observed in samples treated with ozone and temperature (Figures 2B, 2C and 2D), indicating the inactivation of polyphenoloxidase enzyme and reducing the juice color, according to Silva et al. (2015).

The lower absorbance values were observed in Figures $2 \mathrm{~B}$ and $2 \mathrm{C}$ and show a direct relationship with the juice color decrease (Table 2). It appears that the T2 treatment presented lower mean for ICUMSA color, but not unlike T3 and T4 $(p>0.05)$.

Treatments T2, T3 and T4 presented a $63 \%$ reduction of the ICUMSA color in relation to control sample T1. The lower the ICUMSA color, the better the juice quality for the production of lower sugar color.

The inactivation of polyphenoloxidase (PPO) enzyme was interactively affected by chemical treatment (variable concentration) and thermal treatment (fixed variable), simultaneously.

\section{Conclusions}

The combination of the ozone concentration and temperature variables had influence on sugarcane juice color and inactivation of the PPO.

The best result was obtained in treatment with $150 \mathrm{mg} \mathrm{L}^{-1}$ of ozone concentration at $105^{\circ} \mathrm{C}$, which showed a juice color reduction.

\section{References}

Almeida, C. M. A., Lima, S. E. N., Lima, G. S. A., Brito, J. Z., Donato, V. M. T. S., \& Silva, M. V. (2009). Caracterização molecular de cultivares de cana-de-açúcar utilizando marcadores ISSR. Ciência e Agrotecnologia, 33(spe), 1771-1776. http://dx.doi.org/10.1590/S1413-70542009000700012

Azevedo, P. V., Saboya, L. M. F., Dantas Neto, J., Oliveira, F. S., Bezerra, J. R. C., \& Farias, C. H. A. (2014). Disponibilidade energética para a cultura da cana-de-açúcar nos tabuleiros costeiros do estado da Paraíba. Revista Brasileira de Engenharia Agrícola e Ambiental, 18(10), 1031-1038. http://dx.doi.org/10.1590/1807-1929/agriambi.v18n10p1031-1038 
Barbosa, E. A. A., Arruda, F. B., Pires, R. C. M., Silva, T. J. A., \& Sakai, E. (2013). Cana-de-açúcar fertirrigada com vinhaça via irrigação por gotejamento subsuperficial em três ciclos de cana-soca. Revista Brasileira de Engenharia Agrícola e Ambiental, 17(6), 588-594. http://dx.doi.org/10.1590/S1415-43662013000600003

Batista, E. L., Zolnier, S., Ribeiro, A., Lyra, G. B., Silva, T. G. F., \& Boehringer, D. (2013). Modelagem do crescimento de cultivares de cana-de-açúcar no período de formação da cultura. Revista Brasileira de Engenharia Agrícola e Ambiental, 17(10), 1080-1087. http://dx.doi.org/10.1590/S1415-43662013001000009

Campos, C. F., Souza, P. E. A., Coelho, J. V., \& Glória, M. B. A. (1996). Chemical composition, enzyme activity and effect of enzyme inactivation on flavor quality of green coconut water. Journal of Food Processing and Preservation, 20(6), 487-500. http://dx.doi.org/10.1111/j.1745-4549.1996.tb00761.x

Centro de Previsão de Tempo e Estudos Climáticos - CPTEC, \& Instituto Nacional de Pesquisas Espaciais - INPE. Cana mais produtiva e resistente a seca para o Nordeste brasileiro. (2008). Retrieved in 2016, October 28, from http://www.cptec.inpe.br/noticias/noticia/9339from

Fagundes, E. A. A., Silva, T. J. A., \& Bonfim-Silva, E. M. (2014). Desenvolvimento inicial de variedades de cana-de-açúcar em Latossolo submetidas a níveis de compactação do solo. Revista Brasileira de Engenharia Agrícola e Ambiental, 18(2), 188-193. http://dx.doi.org/10.1590/S1415-43662014000200009

Icier, F., Yildiz, H., \& Baysal, T. (2008). Polyphenoloxidase deactivation kinetics during ohmic heating of grape juice. Journal of Food Engineering, 85(3), 410-417. http://dx.doi.org/10.1016/j.jfoodeng.2007.08.002

International Commission for Uniform Methods of Sugar Analysis - ICUMSA. (1935). International Sugar Journal, 37, 180-187.

Jakób, A., Bryjak, J., Wójtowicz, H., Illeová, V., Annus, J., \& Polakovič, M. (2010). Inactivation kinetics of food enzymes during ohmic heating. Food Chemistry, 123(2), 369-376. http://dx.doi.org/10.1016/j.foodchem.2010.04.047

Mandro, J. L.; Magri, N. T. C.; Sartori, J. A. S.; Aguiar, C. L. (2017). ICUMSA colour reduction in concentrated raw sugar solutions by an oxidative process with hydrogen peroxide. Brazilian Journal of Food Technology, 20. http://dx.doi.org/10.1590/1981-6723.11416.

Quintela, M. P., Pedrosa, E. M. R., Willadino, L., Rolim, M. M., Silva, E. F. F., \& David, M. F. L. (2015). Intensity and duration of water deficit on the pathosystem sugarcane $\mathrm{x}$ meloidogyne incognita. Revista Brasileira de Engenharia Agrícola e Ambiental, 19(6), 581-586. http://dx.doi.org/10.1590/1807-1929/agriambi.v19n6p581-586

Santori, J. A. S., Magri, N. T. C., \& Aguiar, C. L. (2015). Clarification of sugarcane juice by hydrogen peroxide: effects of the presence of dextran. Brazilian Journal of Food Technology, 18, 299-309.

Santos, D. H., Silva, M. A., Tiritan, C. S., Foloni, J. S. S., \& Echer, F. R. (2011). Qualidade tecnológica da cana-de-açúcar sob adubação com torta de filtro enriquecida com fosfato solúvel. Revista Brasileira de Engenharia Agrícola e Ambiental, 15(5), 443-449. http://dx.doi.org/10.1590/S1415-43662011000500002

Siles, J. A., Garcia-Garcia, I., Martin, A., \& Martin, M. A. (2011). Integrated ozonation and biomethanization treatments of vinasse derived from ethanol manufacturing. Journal of Hazardous Materials, 188(1-3), 247-253. PMid:21330053. http://dx.doi.org/10.1016/j.jhazmat.2011.01.096

Silva, F. A. S. (2016). ASSISTAT 7.6 BETA - Assistência Estatística. Campina Grande: Universidade Federal de Campina Grande.

Silva, S. B., Luvielmo, M. M., Geyer, M. C., \& Prá, I. (2011). Potencialidades do uso do ozônio no processamento de alimentos. Semina: Ciências Agrárias, 32(2), 659-682. http://dx.doi.org/10.5433/1679-0359.2011v32n2p659

Silva, W. S., Sartori, J. A. S., \& Aguiar, C. L. (2015). Combination effect of ozone and heat treatment for the color reduction in sugarcane juice. Chemical and Process Engineering Research, 35, 75-83.

Zago, E. A., Silva, L. F. L. F., \& Amorim, H. V. (1992). Novo método de hidrólise e determinação potenciométrica para açúcares redutores e açúcares redutores totais. STAB Açúcar, Álcool e Subprodutos, 10, 40-42. 